
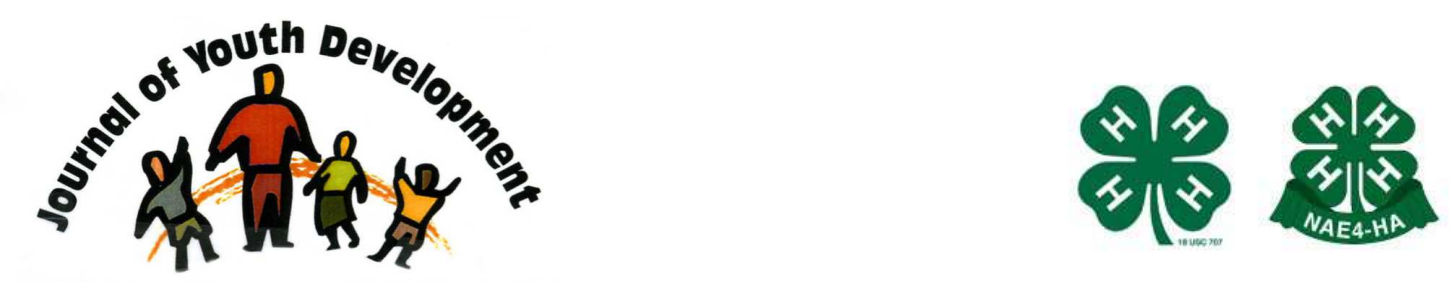

Bridging Research \& Practice

\title{
Training Teens to Teach Agricultural Biotechnology: A National 4-H Science Demonstration Project
}

\author{
Chad Ripberger \\ Rutgers Cooperative Extension of Mercer County \\ Trenton, New Jersey \\ ripberger@njaes.rutgers.edu
}

Lydia B. Blalock

Project Consultant 


\title{
JOURNAL OF YOUTH DEVELOPMENT \\ bridging research and practice

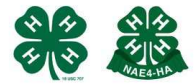

Volume 8, Number 3, Winter 2013

Article 130803FA003

\section{Training Teens to Teach Agricultural Biotechnology: A National 4-H Science Demonstration Project}

\author{
Chad Ripberger \\ Rutgers Cooperative Extension of Mercer County \\ Lydia B. Blalock \\ Project Consultant
}

\begin{abstract}
This article discusses a National 4-H Science agricultural biotechnology demonstration project and the impact of the pilot programs on the teenage leaders and teachers. A total of 82 teenagers were extensively trained, who in turn, engaged 620 youth participants with agricultural biotechnology education in afterschool and summer programs in five states. This article details the national and state level trainings for these teen teachers as well as the content rich partners from agribusinesses, agricultural commodity groups, and universities who supported their involvement. The impact on the content knowledge, science process and life skills, and program development and implementation skills of the teen leaders and teachers was evaluated using multiple instruments over multiple administrations (pre-training, post-training, and post-teaching). Results indicate significant gains in most areas assessed. Project recommendations and future plans are also discussed.
\end{abstract}

\section{Introduction}

Today, many young people are generationally and geographically removed from farming and agriculture. Yet, it is vital that these young leaders and future decision makers understand the critical role of agricultural science innovation in addressing the world's most pressing problems. In 2012, National 4-H Council in partnership with the United Soybean Board (USB) and five Land Grant Universities conducted four, teen led agricultural biotechnology demonstration programs in ten urban areas of Delaware, Illinois, Indiana, Missouri, and Ohio. These programs are part of the larger 4-H Science in Urban Communities Initiative, and were designed using the 4- $H$ Science in Urban Communities Promising Practices Guide available at http://urban4hscience.rutgers.edu (Ripberger, \& Blalock, 2011). 


\section{Teens as Teachers}

The 4-H Youth Development Program has a long history of training and supporting teenagers to teach or co-facilitate youth programs for their peers and/or younger youth. The teens as crossage teachers delivery model has been implemented with a variety of curricula, including healthy living (Emil, Dworkin, \& Skelly, 2007; Ripberger, Devitt, \& Gore, 2009), job readiness (Ripberger, Bovitz, Cole, \& Lyons, 2008), and science (Bird, \& Subramaniam, 2011; Smith \& Enfield, 2002; Utah State University Cooperative Extension, 2011). Lee and Murdock (2002) studied 14 teens as teachers programs, and identified ten essential elements of programs that lead to positive outcomes for the teen teachers and those they teach:
a) dedicated adults who support teens,
b) active teen recruitment,
c) strong curriculum,
d) initial training,
e) ongoing training and support,
f) attention to details,
g) recognition and reward,
h) team building,
i) setting teens up for success, and
j) feedback and evaluation.

Based on their work, several resources have been created to support 4-H professionals developing teens as teachers programs. These resources include a 4-H Afterschool resource guide to help practitioners recruit and train teenagers to work with younger youth in afterschool settings (Junge, 2005) and a more concise 4-H Science fact sheet, Engaging Teens as Teachers through Youth-Adult Partnerships in 4-H Science (Schmitt-McQuitty, 2012).

The agricultural biotechnology project discussed in this article is based on the work of Lee and Murdock and the practices outlined in the Staffing with Teenagers and Teens as Cross-Age Teachers chapter of the 4-H Science in Urban Communities Promising Practices Guide (Ripberger, \& Blalock, 2011). Ripberger and Blalock worked with six 4-H professionals with extensive experience in "teens as teachers" programs to identify "teens as teachers" promising practices in four areas:

a) program planning and evaluation,

b) recruitment,

c) training, and

d) resources and support (see Table 1). 


\section{Table 1}

Staffing with Teenagers and Teens as Cross-Age Teachers Promising Practices

(Ripberger \& Blalock, 2011)

\begin{tabular}{|l|}
\hline Program Planning and Evaluation \\
\hline Read the chapter 4-H Science Program Design - 4-H Science Checklist. \\
\hline Offer authentic, meaningful teaching and/or leadership roles. \\
\hline Make their role special. \\
\hline Provide meaningful recognition. \\
\hline Provide incentives to teens for their time and dedication. \\
\hline Partner with other agencies or organizations that provide youth incentives. \\
\hline Use flexible scheduling practices. \\
\hline Extend service-learning beyond one program. \\
\hline Evaluate teen program performance. \\
\hline Recruitment \\
\hline Recruit teens from a variety of sources. \\
\hline Assess teens interested in becoming program partners. \\
\hline Emphasize the employment process. \\
\hline Training \\
\hline Read the chapter Training Others to Deliver High Quality Science Programming. \\
\hline Provide quality training for teens and their adult partners. \\
\hline Create opportunities to practice. \\
\hline Group youth into teaching teams. \\
\hline Ask youth to visualize the teaching process. \\
\hline Resources and Support \\
\hline Provide research-based curricula and materials. \\
\hline Supportive adult partners are a critical factor in great teen teaching. \\
\hline Ensure that adults working with teens are trained and prepared. \\
\hline Assist teens in reflecting on their teaching experience. \\
\hline
\end{tabular}

A full description of the practices along with a short video featuring the contributors, brief case studies, and suggested resources is available at http://urban4hscience.rutgers.edu/practices/staffing/teens.html.

In addition, a 60-minute webinar about this chapter is available in the 4-H Online Learning Center at http://4h.interactyx.com/login.aspx (Ripberger, Francis, \& Wagoner, 2012).

\section{Need for Agricultural Biotechnology Programming}

Agricultural biotechnology is a "range of tools, including traditional breeding techniques, that alter living organisms, or parts of organisms, to make or modify products; improve plants or animals; or develop microorganisms for specific agricultural uses. Modern biotechnology today includes the tools of genetic engineering" (USDA, n.d., p. 1). To date, agricultural biotechnology has primarily been used to increase crop yields through the development of a variety of transgenic crops that are herbicide tolerant, insect resistant, and/or disease resistant. However, a variety of agricultural biotechnology products are in various stages of research, development, and commercialization that have the potential of addressing some of our most pressing issues related to global food security, nutrition, energy, and sustainability (USDA; National Research Council, 2008; Pew Initiative on Food and Biotechnology, 2001). 
Through 2015, it is estimated that there will be 54,400 annual job openings for those with agricultural college degrees (Goecker, Smith, Smith, \& Goetz, 2010). While the percentage of these opportunities in production agriculture (farming) has declined, $27 \%$ of these jobs will be in science and engineering and $47 \%$ will be in management and business. A shortfall of graduates for these science and business positions is projected as we approach 2015, especially for the anticipated demand for plant geneticists and plant breeders. The 4-H Teens Teaching Youth Agricultural Biotechnology project was designed to help youth increase their knowledge of agricultural biotechnology and to increase their awareness of career opportunities available in this growing field. This project is consistent with the recommendations for $\mathrm{K}-12$ and youth outreach from Transforming Agricultural Education for a Changing World, a report from the National Research Council (2009),

Many of the messages in the report about the changing nature of agriculture also apply to the way that it is portrayed in youth-focused programs. These activities have the same responsibility as agriculture faculty to ensure that the treatment of agriculture in courses and curricula reflects the cutting edge and the increasing focus on issues such as sustainability and concern for the environment. (p. 83)

As a pilot project, 4-H Teens Teaching Youth Agricultural Biotechnology was designed to serve as a foundation for an increased focus on AgriScience programming by $4-\mathrm{H}$.

\section{Project Design}

In 2011 National 4-H Council, with support from the United Soybean Board (USB), solicited interest from 4-H professionals to participate in a year-long "teens as teachers" project focused on agricultural biotechnology. Through a competitive proposal process, four grants of $\$ 25,000$ were awarded to 4-H programs in Delaware, Illinois/Missouri (a partnership), Indiana, and Ohio. Each of these 4-H programs agreed to the overall project objectives and outcome objectives.

\section{Project Objectives}

1. Each demonstration program will include a leadership team composed of four Teen Leaders, at least one 4-H Program professional, and at least one agricultural biotechnology partner from their state soybean board, industry, and/or their Land Grant University.

2. All leadership team members will attend the project kickoff/grantee training, January 11-14, 2012 in Indianapolis, Indiana.

3. The project will engage a total of 80 urban teens and 400 younger youth participants with biotechnology education in order to identify promising practices for future replication with expanded audiences. Eighty urban teens will be recruited and extensively trained to deliver a minimum of 20 hours of biotechnology programming for youth in afterschool, club, and summer/camp programs.

\section{Outcome Objectives}

1. Content Knowledge - Agricultural Biotechnology

a. Participants will increase their knowledge of biotechnology/AgriScience principles and concepts.

b. Participants will increase their awareness of potential careers in agricultural biotechnology fields.

c. Participants will feel comfortable communicating the biotechnology story. 
2. Science Process and Life Skills

a. Participants will increase in 4-H Science Abilities (science process skills) (Worker, 2012).

b. Participants will increase in Life Skills as measured by the Youth, Engagement, Attitudes and Knowledge (YEAK) Survey.

3. Program Development and Implementation

a. Participants will improve their teaching and communication skills.

b. Participants will increase their skills in 4-H Science program design.

c. Participants will understand how to effectively use content rich partners as part of their trainings.

d. Participants will understand how to integrate biotechnology/AgriScience activities from recommended curricula sources into program plans.

\section{Concepts and Related Activities and Curricular Resources}

In the absence of a comprehensive and current 4- $\mathrm{H}$ agricultural biotechnology curriculum, the demonstration program leadership teams were introduced to a variety of activities from suggested curricula at the national training. These activities, along with field trips, presentations from content-rich partners, and computer-based resources, were sequenced to address the following concepts (see Table 2). Suggested curricula included the 4-H AgriScience Online biotechnology activities (Horton, Warkentien, \& Gogolski, 2011) and resources from the Iowa State University Biotech Office (2012). Teams also utilized selected components of an agricultural biotechnology curriculum from The Children's Museum of Indianapolis (2007) and the GetBiotechSmart.com website (United Soybean Board, 2012). 
Table 2

Ag Science Concepts and Related Activities and Resources

\begin{tabular}{|c|c|}
\hline Ag Science Concepts & Selected Activities and Resources \\
\hline $\begin{array}{l}\text { Agricultural Literacy } \\
\text { Agricultural Products } \\
\text { (how and where they are } \\
\text { produced) } \\
\text { Plants \& People - Food, Feed, } \\
\text { Fuel, Fiber } \\
\text { Seed Production } \\
\text { Yield and Yield Trends } \\
\text { Factors Influencing Yield }\end{array}$ & $\begin{array}{l}\text { Bio Plastic from } 4 \text {-H AgriScience Online } \\
\text { Soy Ink from } \underline{4-\mathrm{H} \text { AgriScience Online }} \\
\text { Biomass to Biofuel from 4-H AgriScience Online } \\
\text { Soap - Plant Oils Matter from } 4 \text {-H AgriScience Online } \\
\text { Field trip to seed company addressed seed production, yield } \\
\text { and yield trends, and factors influencing yields. Youth } \\
\text { spoke with staff and toured seed production facilities. }\end{array}$ \\
\hline $\begin{array}{l}\text { Challenges for Agriculture } \\
\text { Global Food Security } \\
\text { Sustainability }\end{array}$ & $\begin{array}{l}\text { Primarily addressed through guest speakers, field trips, PPT, } \\
\text { and video. }\end{array}$ \\
\hline $\begin{array}{l}\text { Intro to Agricultural } \\
\text { Biotechnology } \\
\text { Biotechnology Defined } \\
\text { Historical Perspective } \\
\text { Input and Output Traits } \\
\text { Types of Biotech Crops } \\
\text { Regulation of Biotechnology } \\
\text { Public Concerns Regarding } \\
\text { Biotechnology } \\
\text { International Perspective }\end{array}$ & $\begin{array}{l}\text { History of Agricultural Biotechnology from Agricultural } \\
\text { Biotechnology, pg. 6-11, } 27 \\
\text { Engineering a Better Oil from 4-H AgriScience Online } \\
\text { Trait Testing Activity from Iowa State University Biotech } \\
\text { Office } \\
\text { Bioethics Case Studies from Iowa State University Biotech } \\
\text { Office } \\
\text { Also addressed through guest speakers, field trips, PPT, and } \\
\text { video. Staff from agribusinesses and commodity groups } \\
\text { were especially helpful in addressing input and output traits } \\
\text { and the types of biotech crops. Due to their work in many } \\
\text { countries, the Danforth Plant Science Center was key in } \\
\text { providing a global perspective. }\end{array}$ \\
\hline $\begin{array}{l}\text { Science of Biotechnology } \\
\text { Cell Biology } \\
\text { DNA } \\
\text { Genetics } \\
\text { Genetic Engineering } \\
\text { Tools and Techniques }\end{array}$ & $\begin{array}{l}\text { Cell Model Activities: } \\
\text { Background info from Agricultural Biotechnology, pg. 12-14 } \\
\text { Cell Pudding Pie Model from Field of Genes } \\
\text { DNA Model Activities: } \\
\text { Paper Clip Model from Agricultural Biotechnology, pg. 18-20 } \\
\text { Candy Model (licorice \& gum drops) from } \\
\text { GetBiotechSmart.com (some did similar with pipe } \\
\text { cleaners) } \\
\text { DNA Extraction Activities: } \\
\text { Fruit Smoothie Version from Iowa State University Biotech } \\
\text { Office } \\
\text { Wheat Germ Version from Agricultural Biotechnology, pg. } \\
21-23 \\
\text { Strawberry Version from Pioneer } \\
\text { LEGO Analogy for Sequencing } \\
\text { In Delaware, Missouri, and Illinois, participants completed } \\
\text { PCR and microarray lab activities at the Delaware } \\
\text { Biotechnology Institute and the Danforth Plant Science } \\
\text { Center. }\end{array}$ \\
\hline $\begin{array}{l}\text { Agricultural Biotechnology Career } \\
\text { Awareness }\end{array}$ & $\begin{array}{l}\text { Youth met many in the field of biotechnology through field } \\
\text { trips and guest speakers. Youth (both teens and younger } \\
\text { participants) visited the labs and greenhouses of many } \\
\text { partnering agribusinesses and organizations. }\end{array}$ \\
\hline
\end{tabular}




\section{National Kickoff Training}

The Kickoff Training was a four-day program held in Indianapolis, Indiana for 16 Teen Leaders and 16 adults serving on state leadership teams. Program kickoff partners included USB, the Indiana Soybean Alliance (new uses, communicating the biotech story, and a panel of Purdue students and faculty from the Soybean Innovation Contest), Purdue University (Biotechnology 101, DNA extraction and sequencing activities), Beck's Hybrids (seed production, input and output traits, trait testing activity, tour), Dow AgroSciences (biotechnology and global food security, product pipeline, tour), and Adayana, Inc. (GetBiotechSmart.com). In addition to presentations and tours from partners, the youth also experienced several activities from suggested curricula and practiced teaching these activities on the last day. Participants also had time to brainstorm ideas for teen recruitment, training, and program implementation.

\section{State Level Teen Recruitment and Training}

After attending the national kickoff training, state leadership teams (four teens, 4-H professional, and content rich partner) were responsible for recruiting additional teen teachers and planning and implementing a 15-hour training to help prepare them for their responsibilities. State teams were strongly encouraged to utilize content rich partners from agribusinesses, universities, and agricultural commodity groups in their training events. Highlights of their partners, trainings, and programming are below.

\section{Demonstration Program Highlights and Content Rich Partners}

Delaware (Claymont, Dover, Hartly, and Wilmington)

Delaware 4-H partnered with Boys and Girls Club in Clayton, the Delaware Housing Authority in Dover, Urban Promise in Wilmington, and a local school to deliver four agricultural biotechnology summer camps from June through August. The program's content rich partners included the Delaware Biotechnology Institute, a University of Delaware agronomist, and a member of the Delaware Soybean Board. In addition to hosting part of the two-day state teen training in March, the Delaware Biotechnology Institute also allowed access to research labs and provided activities for the youth camp participants. In addition, the Delaware team also incorporated several of the biotech activities into the annual science adventure camp.

Illinois/Missouri (Cahokia and Madison, Illinois; Kansas City and St. Louis, Missouri) Illinois and Missouri 4-H programs joined forces to implement nine 20-hour programs with afterschool, camp, and summer school partners in the greater St. Louis and Kansas City areas. From the beginning, the program benefitted from the expertise of Dr. Terry Woodford-Thomas of the Danforth Plant Science Center, who hosted a weekend planning retreat in January and the weekend teen training in February. Dr. Woodford-Thomas also assisted with activities and mentoring the Teen Teachers. In addition to their regular programming, the teenagers incorporated agricultural biotechnology activities into the Missouri State 4-H Congress in May and the Youth Futures Conference in July. The program was presented to afterschool professionals at the Midwest Regional Science Conference.

Indiana (Columbus and Lafayette)

Two county 4-H educators partnered to deliver the program in afterschool sites in Columbus and Lafayette. Agricultural biotechnology content was also incorporated into two three-day campus-based summer camps in June, Purdue 4-H Roundup and one of the Purdue 4-H Science Workshops (PINE-Plants, Insects, Natural Resources, Environment). Dr. Kathryn Orvis, State 4-H Specialist, served as the primary content partner, lending a background in plant science and biotechnology education to the Indiana team. Dr. Orvis was instrumental in training the 
Teen Teachers and in engaging other content rich partners such as the Biotechnology Learning Center of the Children's Museum of Indianapolis, host of part of the two-day teen training in February.

Ohio (Dayton)

The Teen Leaders conducted a pilot of the program at a partnering afterschool site in Dayton, Ohio from February to April before recruiting and training additional teens to deliver the program as part of the six-week Adventure Central summer camp in June and July for 111 youth. The agricultural biotechnology training was incorporated into the weeklong teen counselor training prior to camp. In addition to the camp-based programming, the Ohio 4-H team partnered with the Ohio Soybean Council and the Ohio BioProducts Innovation Center to coordinate a day trip to The Ohio State University to meet with faculty from Food Science, Horticulture and Crop Science, and Agricultural Engineering.

\section{USA Science and Engineering Festival}

All leadership teams (teens and staff) traveled to Washington DC in April 2012 to represent National 4-H and this project at the USA Science and Engineering Festival-the largest celebration of science in the US - featuring over 500 interactive exhibits for approximately 500,000 people. In addition to time spent staffing the $4-\mathrm{H}$ booth, the teens participated in activities from a variety of universities, federal agencies, and science centers.

\section{Project Evaluation}

Teen Teachers and Teen Leaders were evaluated using multiple instruments over multiple administrations. Teen Leaders were Teen Teachers who had the additional responsibility of attending the National Kickoff Training and planning and implementing state trainings for their peers. Instruments included a Knowledge Assessment, several open-ended questions, a Retrospective Assessment, and the Youth Engagement, Attitudes, and Knowledge Survey (YEAK). In addition, the adult program leaders were asked to provide feedback regarding the project.

\section{Methods}

Knowledge Assessment

A 29-item (36 points) Knowledge Assessment was developed specifically for this project. The assessment included items on genetics, the science of biotechnology, input and output traits, types of biotechnology crops, biotechnology benefits and concerns, and biotechnology regulation. Question formats included multiple choice, matching, true/false, and short answer. The assessment was administered to the Teen Teachers and Leaders three times, pre-training, post-training, and post-teaching. Scores were assigned based upon number of correct items. Results were analyzed with SPSS using paired t-tests for dependent samples.

\section{Open-ended Questions}

The teens were asked to answer three open-ended questions about their experiences. The questions included:

1. What are the three (3) most valuable things you learned about biotechnology this week?

2. What was the most valuable part of this training?

3. What was the most valuable part of this biotechnology program experience? Responses were analyzed by clustering the answers into similar groups. The authors then looked for emerging themes, and labeled the clusters accordingly. 


\section{Retrospective Assessment}

A 7-item Retrospective Assessment was also developed for this project to assess how students felt about their:

- understanding of the science of biotechnology,

- awareness of careers in biotechnology,

- confidence to speak intelligently about biotechnology,

- confidence to implement the 4-H biotechnology program in their state,

- confidence to teach/facilitate biotechnology activities with other youth,

- confidence to work as part of a team to develop the program, and

- awareness of the many opportunities to engage content-rich partners in programming. The response set included strongly disagree (1), disagree (2), agree (3), and strongly agree (4). The assessment was administered twice, once after the trainings and again after completion of the teens' teaching responsibilities. Results were analyzed with SPSS using paired t-tests for dependent samples.

\section{Youth Engagement, Attitudes, and Knowledge Survey (YEAK)}

The YEAK survey is a national instrument developed to assess the impact of 4-H Science programming on youth participants (Mielke, LaFleur, \& Sanzone, 2010). The survey was administered twice to the Teen Teachers, before training (pre-survey) and again after completing their teaching responsibilities (post-survey). The survey asked youth to provide a self-report on personal decision making, critical thinking, and problem solving skills. The survey also included a series of questions intended to gauge respondents' enthusiasm for science as a subject that touches their everyday lives. Respondents were also asked to describe their own science skills. Results were analyzed using SPSS by Policy Studies Associates, Inc.

\section{Program Leaders}

Program leaders were asked to identify promising practices in program development, implementation, and evaluation that could be shared with others to enhance future programming. Responses were analyzed by clustering the answers into similar groups. The authors then looked for emerging themes, and labeled the clusters accordingly.

\section{Results}

The program was evaluated using several instruments over multiple administrations. Often, a single instrument was used to assess multiple dimensions of the project. As this is a program evaluation, results are reported here according to project and outcome objectives, instead of reporting by instrument.

\section{Project Objectives}

Each of the four demonstration programs included a leadership team composed of four Teen Leaders, at least one 4-H Program professional, and at least one agricultural biotechnology partner from their state soybean board, industry, and/or their Land Grant University. All leadership team members attended the project kickoff/grantee training, January 11-14, 2012 in Indianapolis, Indiana.

Eighty-two teenagers, an average of 20.5 per demonstration program, were trained as Teen Teachers. Demographics of the Teen Teachers were as follows: 49\% African American, 48\% White, and 3\% American Indian or Asian. 4\% were Hispanic. $60 \%$ were female. Seventy-six percent $(76 \%)$ lived in urban or metropolitan areas. This program was the first experience with $4-\mathrm{H}$ for $45 \%$ of the teens, and $47 \%$ had participated in $4-\mathrm{H}$ for three or more years (see Fig. 1 ). 
Figure 1

Demographics: Teen Teachers
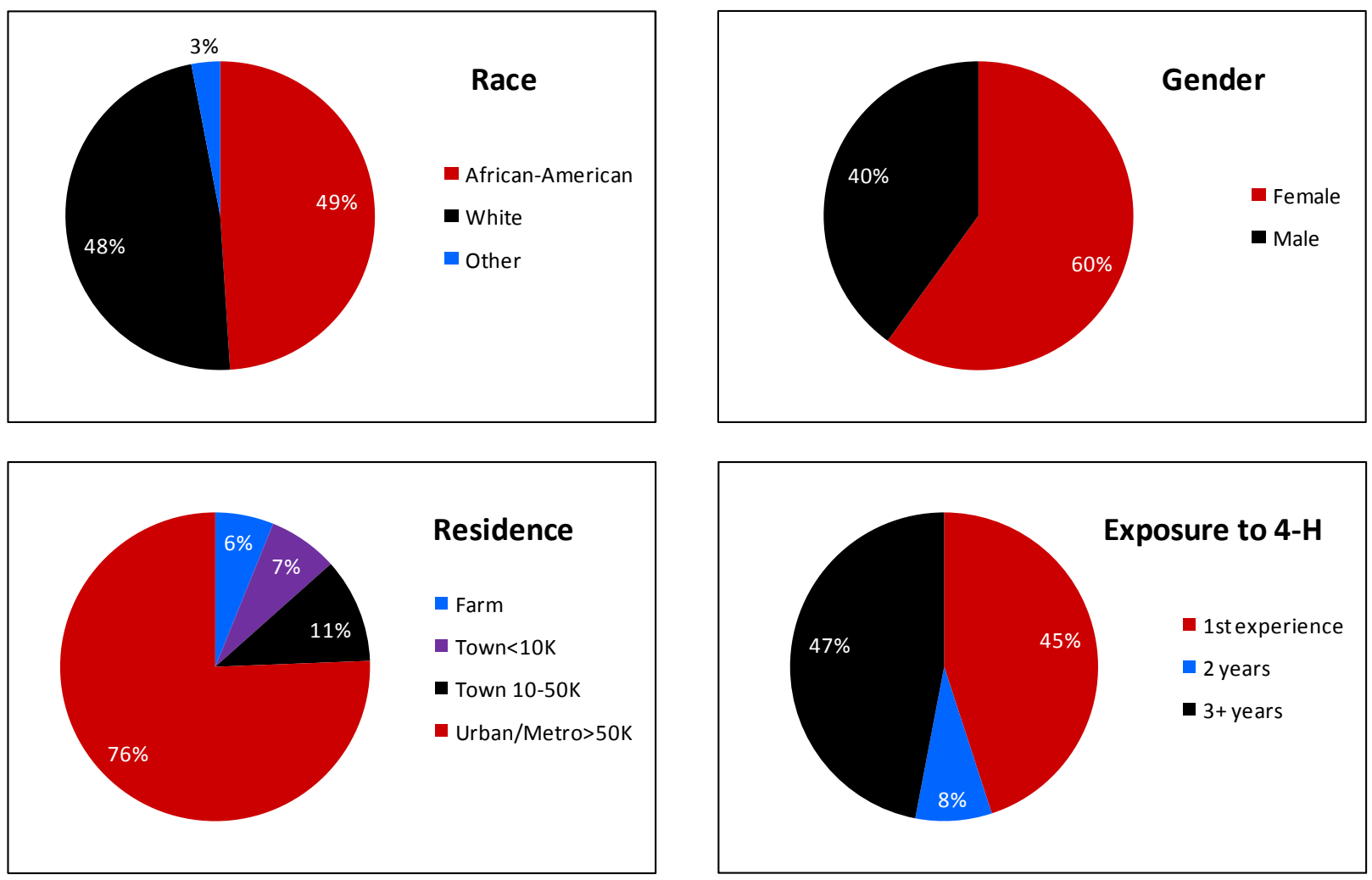

Eighteen 20-hour programs were implemented by the Teen Teachers. The programs reached a total of 620 youth participants, an average of 155 per demonstration program. Demographics of the youth participants were as follows: $71 \%$ African American; 27\% White; and 2\% either American Indian, Asian, or Pacific Islander. In addition, $10 \%$ were Hispanic and $53 \%$ were female. Youth came from all grade levels: $9 \%$ lower elementary, 36\% upper elementary, $39 \%$ middle school, and $16 \%$ high school. Eighty-five ( $85 \%)$ of the youth lived in urban or metropolitan areas (see Fig. 2). 
Figure 2

Demographics: Youth Participants
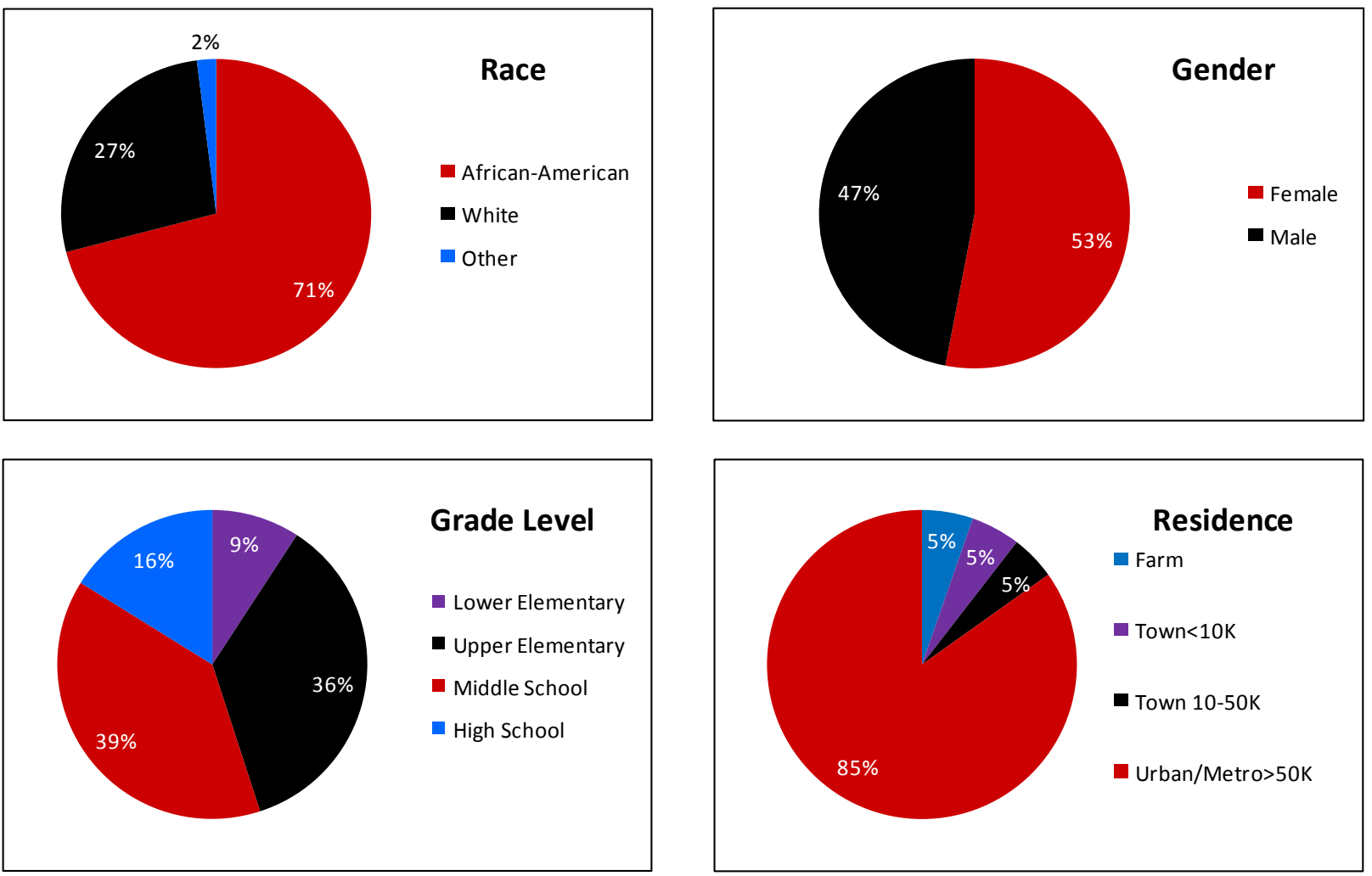

Table 3 provides a snapshot of the expected and achieved project objectives. All stated objectives were achieved.

Table 3

Reach At-a-Glance

\begin{tabular}{|c|l|c|}
\hline Achieved & \multicolumn{1}{|c|}{ Item } & Expected \\
\hline 4 & $\begin{array}{l}\text { Demonstration programs in 5 states: Delaware, Illinois/Missouri } \\
\text { (partnership), Indiana, Ohio }\end{array}$ & 4 \\
\hline 10 & Urban areas & 4 \\
\hline 16 & Teen Leaders & 16 \\
\hline 18 & Out-of-school Time (OST) sites/programs & 80 \\
\hline 82 & Teen Teachers (includes Teen Leaders) & 400 \\
\hline 620 & Youth participants & \\
\hline
\end{tabular}

Though not one of the stated objectives, 800 additional youth were reached at the USA Science and Engineering Festiva/ in Washington, DC (April 2012). Leadership teams from the four demonstration programs led a DNA Extraction activity for participants. 


\section{Outcome Objectives}

Agricultural Biotechnology Knowledge and Career Awareness

The Teen Teachers were expected to: increase knowledge of agricultural biotechnology principles and concepts, increase awareness of potential careers in agricultural biotechnology fields, and to become more comfortable communicating the biotechnology story. The Knowledge Assessment was developed to track changes in the teens' knowledge over the course of the project. It was administered three times, pre-training ( $n=73)$, post-training $(n=72)$, and post-teaching $(n=40)$.

The teens demonstrated statistically significant $(p<0.05)$ improvements on the Knowledge Assessment over time. Teen Leaders, however, scored significantly better than Teen Teachers on the post-training and post-teaching administrations (see Figure 3).

Figure 3

Knowledge Assessment Scores

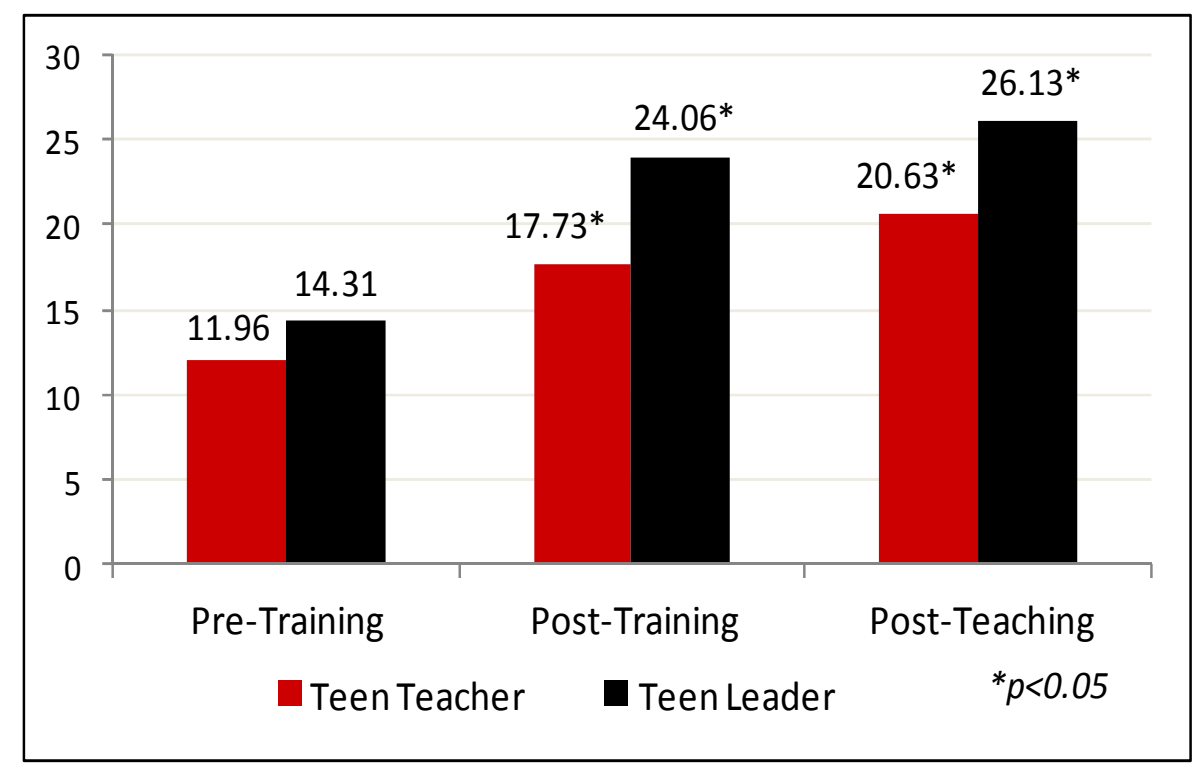

Teen Teachers were also asked an open-ended question in the pre- and post-assessments: What are the three most valuable things you learned about biotechnology? Results tended to cluster around seven major themes, though $19 \%(n=28)$ of the responses did not fall into any of the themes (see Table 4). 


\section{Table 4}

Most Valuable Things Learned About Biotechnology $(n=144)$

\begin{tabular}{|l|c|}
\hline \multicolumn{1}{|c|}{ Concept } & Number Responses \\
\hline $\begin{array}{l}\text { Breadth of Biotechnology (it's } \\
\text { everywhere, used beyond farming, in the } \\
\text { supermarkets, affects our lives every day) }\end{array}$ & 24 \\
\hline $\begin{array}{l}\text { Science of Biotechnology (cells, DNA, } \\
\text { genetics) }\end{array}$ & 24 \\
\hline $\begin{array}{l}\text { Bio-products (soybeans are a huge part of } \\
\text { many things used daily, lots of alternatives to } \\
\text { crude oil, bio-plastics are eco-friendly, can } \\
\text { use soybeans to make common products) }\end{array}$ & 23 \\
$\begin{array}{l}\text { Application of Biotechnology (biotech } \\
\text { traits, longer shelf life, can drastically } \\
\text { improve a plant's genetic traits, make plants } \\
\text { healthier) }\end{array}$ & 17 \\
\hline $\begin{array}{l}\text { Careers in Biotechnology (a rapidly } \\
\text { growing field, opportunities are limitless, } \\
\text { many different scientists for this field, there } \\
\text { are many careers to choose from that involve } \\
\text { biotechnology) }\end{array}$ & 10 \\
\hline $\begin{array}{l}\text { Food Security (can produce more food for a } \\
\text { growing population) }\end{array}$ & \\
\hline $\begin{array}{l}\text { Environment (examples of how it positively } \\
\text { impacts the environment) }\end{array}$ & 9 \\
\hline
\end{tabular}

A 7-item Retrospective Assessment was administered twice to Teen Teachers, after training and again after teaching. It included items that asked teens about their:

- understanding of the science of biotechnology,

- awareness of careers in biotechnology, and

- confidence to speak intelligently about biotechnology.

T-test analyses of both administrations ( $n=39$ pairs) indicated statistically significant $(p<0.05)$ improvements across all items (see Figure 4). 
Figure 4

Retrospective Assessment: Biotechnology Items ( $n=39$ pairs)

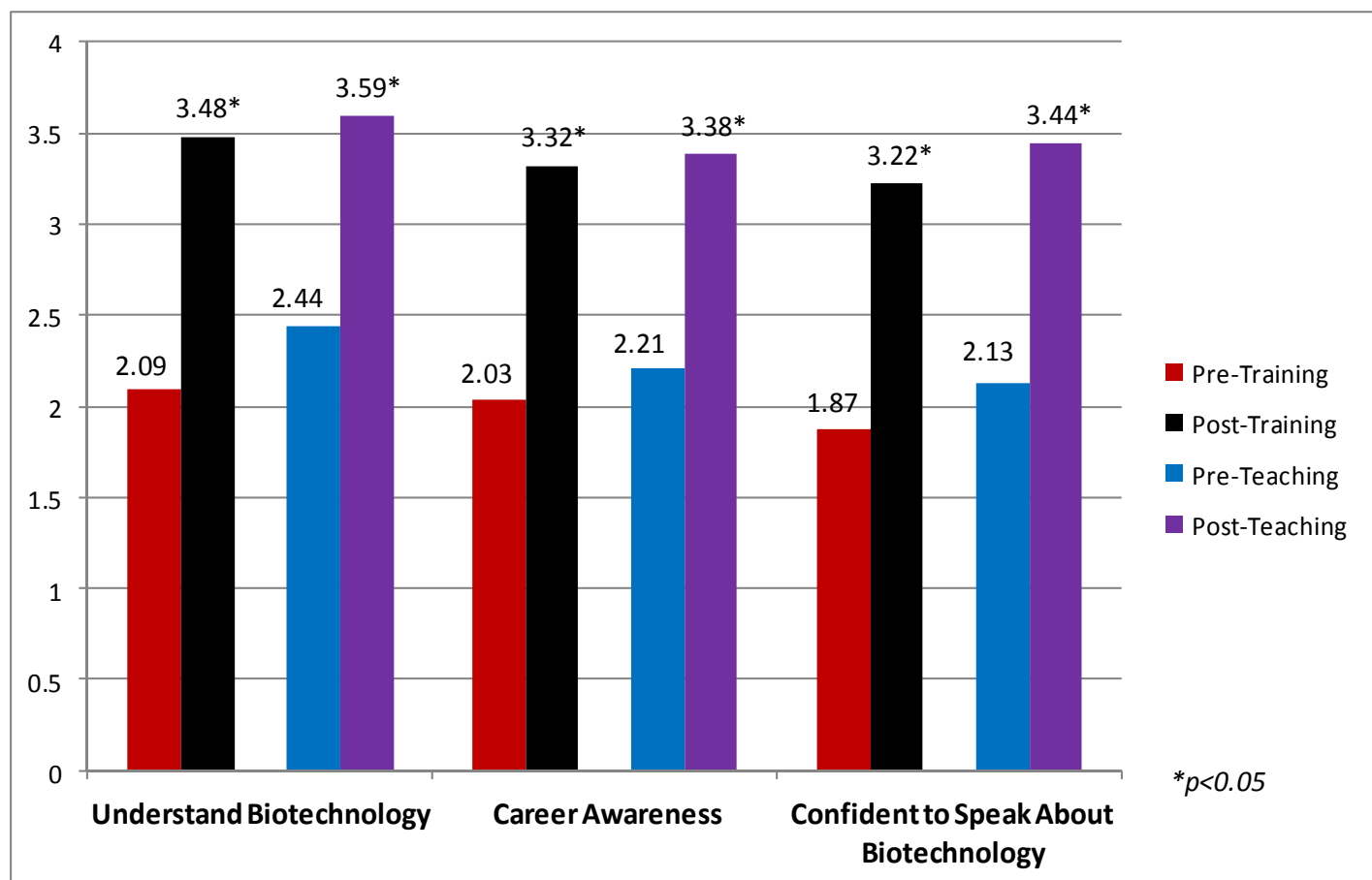

Science Process and Life Skills

It was expected that the Teen Teachers would exhibit increases or gains in 4-H Science Abilities (science process skills) and the Life Skills measured by the YEAK survey. A total of 49 teens returned both the pre- and post-survey. Results for selected science and life skills can be found in Table 5.

Table 5

YEAK Survey Results (selected)

\begin{tabular}{|l|c|c|}
\hline \multicolumn{1}{|c|}{ Item } & \multicolumn{1}{|c|}{$\begin{array}{c}\text { Percent } \\
\text { Seporting }\end{array}$} & $\begin{array}{c}\text { Number of } \\
\text { Matched Pairs }\end{array}$ \\
\hline \multicolumn{1}{|c|}{ Life Skills } & \multicolumn{2}{|c|}{ Increased Confidence } \\
\hline I can analyze the results of a scientific investigation. & $51 \%(n=20)$ & 39 \\
\hline I can communicate a scientific procedure to others. & $45 \%(n=18)$ & 40 \\
\hline I can use science terms to share my results. & $43 \%(n=17)$ & 40 \\
\hline $\begin{array}{l}\text { I can design a scientific procedure to answer a } \\
\text { question. }\end{array}$ & $41 \%(n=16)$ & 39 \\
\hline \multicolumn{2}{|c|}{ Increased Behavior } \\
\hline $\begin{array}{l}\text { When solving a problem I compare each possible } \\
\text { solution with others to find the best one. }\end{array}$ & $45 \%(n=20)$ & 44 \\
\hline I compare ideas when thinking about a topic. & $38 \%(n=17)$ & 45 \\
\hline
\end{tabular}


Program Development and Implementation Skills and Abilities

The project was designed to increase the Teen Teachers' skills and understanding in:

(a) teaching and communication, (b) program design, (c) including content-rich partners in trainings, and (d) integrating biotechnology/AgriScience activities into program plans.

The 7-item Retrospective Assessment included items that asked teens about their:

- confidence to implement the 4-H biotechnology program in my state,

- confidence to teach/facilitate biotechnology activities with other youth,

- confidence to work as part of a team to develop the program, and

- awareness of the many opportunities to engage content-rich partners in programming. Analyses of both administrations ( $n=39$ pairs) indicated statistically significant $(p<0.05)$ improvements across all items (see Figure 5).

Figure 5

Programming Skills and Abilities ( $n=39$ pairs)

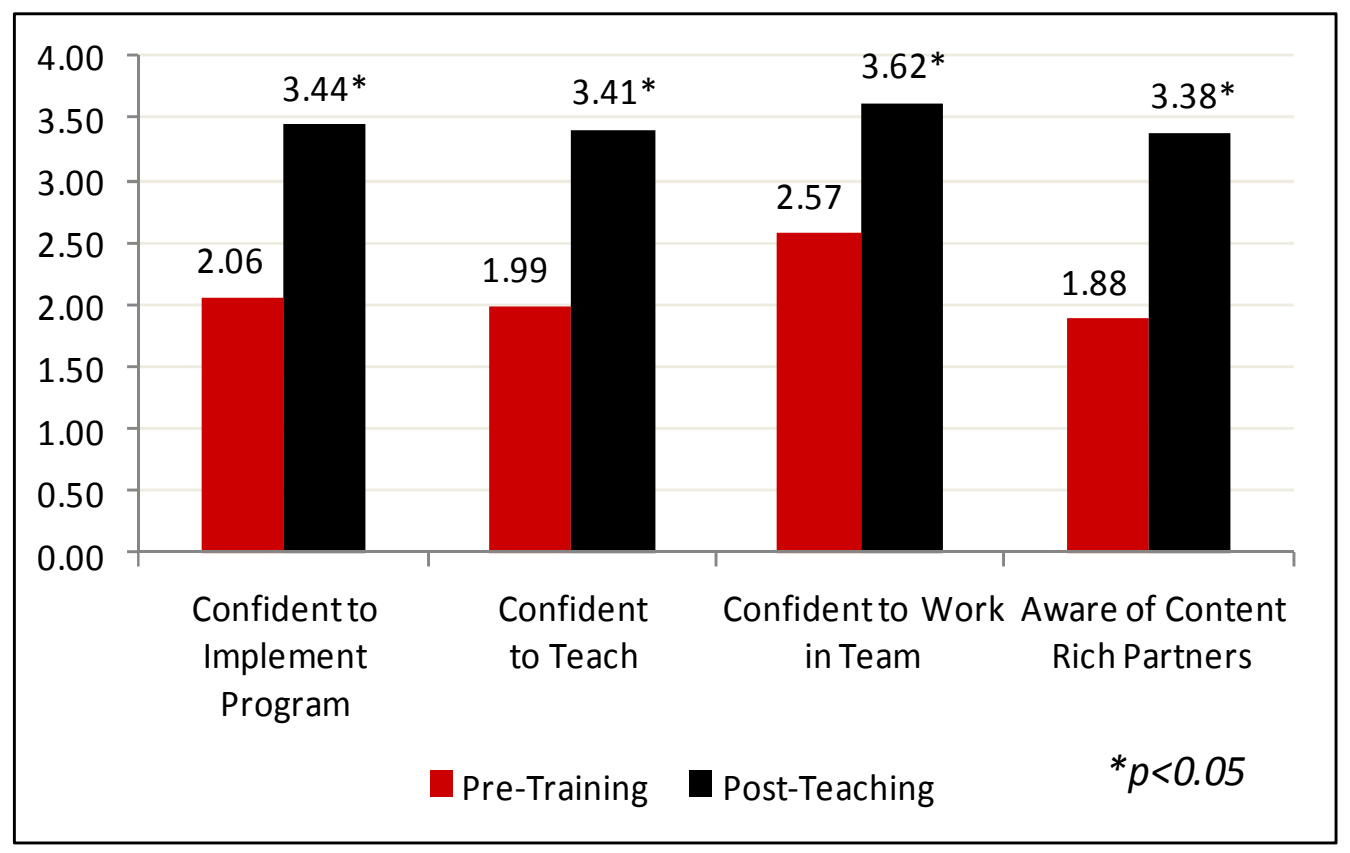

Teen Teachers' Perceptions of Most Valuable Components of Training and Program

Teen Teachers were asked to provide responses to several open-ended questions in the preand post-assessments. These questions were designed to illicit feedback about the overall project as well as the trainings (see Table 6). 
Table 6

Teen Teachers' Perceptions of Training and Program

\begin{tabular}{|l|l|c|}
\hline \multicolumn{1}{|c|}{ Item } & \multicolumn{1}{c|}{ Responses } & $\begin{array}{c}\text { Number } \\
\text { Responding }\end{array}$ \\
\hline $\begin{array}{l}\text { What was the most } \\
\text { valuable part of this } \\
\text { training? }(n=67)\end{array}$ & $\begin{array}{l}\text { Learning about project content and how to } \\
\text { teach it }\end{array}$ & 34 \\
\cline { 2 - 3 } & $\begin{array}{l}\text { Gaining confidence to speak in front of } \\
\text { others/practice teaching or teachbacks }\end{array}$ & 9 \\
\cline { 2 - 3 } & $\begin{array}{l}\text { Interacting with a variety of people involved in } \\
\text { biotechnology and visiting their work places }\end{array}$ & 8 \\
\cline { 2 - 3 } & The experience of working together as a team & 6 \\
\hline $\begin{array}{l}\text { What was the most } \\
\text { valuable part of this } \\
\text { biotechnology program } \\
\text { experience? }(n=37)\end{array}$ & Learning about agriculture and biotechnology & 11 \\
\cline { 2 - 3 } & The experience of teaching & 11 \\
\cline { 2 - 3 } & $\begin{array}{l}\text { Life/job experience (e.g., leadership, } \\
\text { teamwork) }\end{array}$ & 5 \\
\cline { 2 - 3 } & Meeting so many new people & 4 \\
\hline
\end{tabular}

The YEAK post-survey asked teens to select three things (from a list of 10 items) they liked best about the program as a measure of their opinions of the program environment. Teens selected three items most often:

- $67 \%$ - the opportunity to do hands-on activities and projects;

- $47 \%$ - the opportunity to demonstrate what they have learned in front of others; and

- $41 \%$ - that adult staff, leaders, and volunteers were kind and caring.

Promising Practices Identified by Program Leaders

The four Demonstration Programs developed and implemented programs according to principles outlined in the 4-H Science in Urban Communities Promising Practices Guide

(http://urban4hscience.rutgers.edu). When asked to identify five "Promising Practices" for this project, Program Directors considered the items in Table 7 especially important. 


\section{Table 7}

Promising Practices Identified by Program Leaders

\begin{tabular}{|c|c|}
\hline Principle & Practice \\
\hline \multirow[t]{2}{*}{$\begin{array}{l}\text { 4-H Science Core Principles and } \\
\text { Program Design }\end{array}$} & $\begin{array}{l}\text { Teen Involvement in Program Design. Teen leaders } \\
\text { must be intimately involved in all aspects of program } \\
\text { planning, curriculum development, training, and } \\
\text { teaching. }\end{array}$ \\
\hline & $\begin{array}{l}\text { Frequency and Duration. After-school and summer } \\
\text { programs should meet for a minimum of } 20 \text { hours to } \\
\text { allow adequate time for youth to master basic } \\
\text { concepts. }\end{array}$ \\
\hline $\begin{array}{l}\text { Partnering with Afterschool and } \\
\text { Summer Program Providers }\end{array}$ & $\begin{array}{l}\text { Roles and Responsibilities. Partnership agreements } \\
\text { should clearly outline all roles, requirements, and } \\
\text { expectations. }\end{array}$ \\
\hline \multirow[t]{3}{*}{ Engaging Content Rich Partners } & $\begin{array}{l}\text { Colleges and Universities. Faculty, staff, and students } \\
\text { can serve as content rich volunteers for training, } \\
\text { activities, supplies, and getting youth on-campus. } \\
\text { Utilize University resources (research, curricula, labs, } \\
\text { etc.). }\end{array}$ \\
\hline & $\begin{array}{l}\text { Science Centers and Museums. These institutions } \\
\text { have resources to assist with field trips, training, and } \\
\text { activities. }\end{array}$ \\
\hline & $\begin{array}{l}\text { Content Rich Volunteers. Include representatives } \\
\text { from science/agricultural related } \\
\text { businesses/institutions and commodity groups on the } \\
\text { leadership team. They can also provide assistance } \\
\text { with program implementation. }\end{array}$ \\
\hline \multirow[t]{4}{*}{$\begin{array}{l}\text { Staffing with Teenagers and Teens as } \\
\text { Cross-Age Teachers }\end{array}$} & $\begin{array}{l}\text { Recruitment. Develop a detailed position description } \\
\text { including expectations and time commitment } \\
\text { required. }\end{array}$ \\
\hline & $\begin{array}{l}\text { Training. Provide quality training for teens. Include } \\
\text { adequate time to practice and reflect upon all } \\
\text { lessons. }\end{array}$ \\
\hline & $\begin{array}{l}\text { Program Implementation. Create teaching teams to } \\
\text { provide support and accountability. }\end{array}$ \\
\hline & $\begin{array}{l}\text { Make Role Special. Provide customized t-shirts so } \\
\text { teens will stand out and to foster a sense of } \\
\text { inclusiveness. }\end{array}$ \\
\hline
\end{tabular}

\section{Discussion and Recommendations}

\section{Value of Content Rich Partners}

State teams engaged content rich partners to assist with program planning, curriculum, equipment and resources for activities, facilities, state trainings, and ongoing teen teacher mentoring. Based on evaluation results, and consistent with recommendations in the 4-H Science in Urban Communities Promising Practices Guide, the Teen Teachers and 4- $\mathrm{H}$ professionals both recognized significant value in working with these partners. The Teen Teachers identified interactions with partners as one of the most valuable components of the 
training and of the overall program experience. One teen succinctly stated that, "Connecting and hearing from a variety of people with different jobs and experiences in biotechnology" was an important component of the program experience. The Program Directors also identified several practices related to partnerships as being the most critical to the success of the programs. "The level of partner support within the state has been amazing and continues to grow all of the time... . These were all new resources that we had not engaged with previously."

The following recommendations are based upon these results. Program leaders should:

(a) actively seek out content rich partners to assist in all aspects of program planning, implementation, and evaluation;

(b) carefully choose program partners who understand and are willing to fulfill program responsibilities; and

(c) engage partners who enjoy and can work effectively with youth from a positive youth development perspective.

\section{Knowledge Gains - Teen Leaders vs. Teen Teachers}

The Teen Leaders scored significantly better $(p<0.05)$ than the Teen Teachers on the posttraining and post-teaching administrations of the Knowledge Assessment. There are several possible reasons for this outcome. The Teen Leaders were carefully selected for their State Leadership Team based on leadership abilities, maturity, responsibility, and demonstrated interest in science. Teen Leaders also benefitted from attending the four-day national training with numerous activities, presentations, and tours. In addition, Teen Leaders had to further process the information and activities in order to plan and implement state trainings for the additional Teen Teachers prior to implementing the programming.

The following recommendations are based upon the differences in evaluation results between the Teen Leaders and Teen Teachers.

1. Program Leaders should use the same care and focus in recruiting Teen Teachers as used when recruiting Teen Leaders.

2. The state level training for Teen Teachers should mirror the duration and scope of the National Training, including emphasis on participation by content rich partners.

3. Teen Teachers should be given additional opportunities to process the information presented at the initial state training and to practice the selected activities prior to teaching.

\section{Teaching as Most Useful Component}

The Teen Teachers identified the opportunity for teachbacks or to practice teaching as one of the most valuable components of the training. In addition, Teen Teachers reported that teaching experiences during program implementation was one of the most valuable parts of the overall program (this item tied with content knowledge). The Program Directors also identified teachbacks or practice teaching as a critical element of the training for building confidence in the teens and the teens' ability to effectively teach the activities. The importance of teachbacks and practice teaching cannot be overstated. These results are similar to those achieved by the Teen Reaching Youth (TRY) STEM program led by Utah State University Cooperative Extension (2011).

\section{Curriculum Development for Future Programming}

While the individual programs drew from a collection of sources such as 4-H AgriScience Online and the Iowa State University Office of Biotechnology, development of a unified curriculum is 
strongly recommended. Based on the experiences of the Program Directors, partners, and Teen Teachers:

1. The scope and sequence of activities should be developed based on gaps in resources currently available,

2. Activities must be specifically developed for delivery by Teen Teachers,

3. The agricultural literacy component of the curriculum must be emphasized before biotechnology concepts - to provide a foundation in basic agricultural production practices, and

4. A strong international perspective is vital for youth to develop a global view of food production and utilization.

The success of this Project demonstrates the potential impact of this type of programming. Supportive adults, content rich partners, appropriate curriculum, initial training, and ongoing support are key elements to developing and implementing a sustainable teens as teachers $4-\mathrm{H}$ Science program. The authors are currently exploring opportunities to enhance and expand this Project, as well as to bolster the "teens as teachers" approach in other 4-H Science areas.

Acknowledgements: This project was funded by National 4-H Council through a grant from the United Soybean Board. Directors of the demonstration programs included Nate Arnett, Ohio State University Extension; Kristin Cook, University of Delaware Extension; Stephanie Femrite, Purdue University Extension; and Steve Wagoner, University of Illinois Extension. Kathryn Orvis, Ph.D., Purdue University, served as the primary content expert for the national training. Policy Studies Associates administered the YEAK survey.

\section{References}

Bird, M., \& Subramaniam, A. (2011). Teens as teachers enhance environmental education and personal skills through service learning. In A. Subramaniam, K. Heck, R. Carlos, \& S. Junge (Eds.), Advances in youth development: Research and evaluation from the University of California Cooperative Extension 2001-2010 (pp. 32-40). Davis, CA: University of California Agriculture and Natural Resources.

Emil, C., Dworkin, J., \& Skelly, C. (2007). Youth teaching youth: Evaluation of the alcohol/tobacco decisions cross-age teaching program. The Forum for Family and Consumer Issues, $12(2)$.

Goecker, A.D., Smith, P.G., Smith, E., \& Goetz, R. (2010). Employment opportunities for college graduates in food, renewable energy, and the environment, United States, 2010-2015. Retrieved from http://www3.ag.purdue.edu/USDA/employment/Documents/USDAEmployOp2010.pdf

Horton, R.L., Warkentien, C., \& Gogolski, J. (2011). 4-H agriscience biotechnology activities. Retrieved from http://www.4-h.org/agriscience/

Iowa State University. (2012). Office of Biotechnology Outreach Education website. Retrieved from http://www.biotech.iastate.edu/outreach.html

Junge, S. (2005). Teens as volunteer leaders: Recruiting and training teens to work with younger youth in after-school programs. Chevy Chase, MD: National 4-H Council. 
Lee, F.C.H. \& Murdock, S. (2001). Teens as teachers programs: Ten essential elements. Journal of Extension, 39(1). Retrieved from http://joe.org/joe/2001february/rb1.html

Mielke, M., LaFleur, J., \& Sanzone, J. (2010). 4-H Science, Engineering and Technology (SET) Initiative: Youth Engagement, Attitudes, and Knowledge Study. Retrieved from http://www.4h.org/about/youth-development-research/science-program-research/

National Research Council. (2008). Global challenges and directions for agricultural biotechnology: Workshop report. Washington, DC: The National Academies Press.

National Research Council. (2009). Transforming agricultural education for a changing world. Washington, DC: The National Academies Press.

Pew Initiative on Food and Biotechnology. (2001). Harvest on the horizon: Future uses of agricultural biotechnology. Retrieved from http://www.pewtrusts.org/our work report detail.aspx?id=33392

Ripberger, C., \& Blalock, L.B. (2011). Staffing with teenagers and teens as cross-age teachers. In 4-H Science in urban communities promising practices guide (pp. 92-99). Retrieved from http://urban4hscience.rutgers.edu

Ripberger, C., Bovitz, L., Cole, D., \& Lyons, R. (2008). Teenagers as volunteer cross-age teachers in out-of-school programs: Introducing job readiness skills to middle school youth. The International Journal of Volunteer Administration, 24 (6), 72-79.

Ripberger, C., Devitt, A., \& Gore, S. (2009). Training teenagers as food and fitness ambassadors for out-of-school programs. Journal of Extension, 4オ5). Retrieved from http://www.joe.org/joe/2009october/iw5.php

Ripberger, C., Francis, D., \& Wagoner, S. (2012). Teenagers as cross-age teachers [Webinar]. Retrieved from http://4h.interactyx.com/login.aspx

Schmitt-McQuitty, L. (2012). Engaging teens as teachers through youth-adult partnerships in 4-H Science [Fact sheet]. Retrieved from http://www.ca4h.org/files/142237.pdf

Smith, M.H., \& Enfield, R.P. (2002). Training 4-H teen facilitators in inquiry-based science methods: The evaluation of a "step-up" incremental training model. Journal of Extension, 40(6). Retrieved from http://www.joe.org/joe/2002december/a3.php

The Children's Museum of Indianapolis. (2007). Yesterday, today and tomorrow: Agricultural biotechnology: A grade 6-8 unit of study. Retrieved from http://www.childrensmuseum.org/sites/default/files/files/\%20TCM\%20BIOTECH\%20UOS.pdf

United Soybean Board. (2012). GetBiotechSmart.com [Website]. Retrieved from http://getbiotechsmart.com/.

United States Department of Agriculture. (n.d.). USDA's agricultural biotechnology website: Frequently asked questions on biotechnology. Retrieved from http://www.usda.gov/wps/portal/usda/usdahome?navid=BIOTECH) 
Utah State University Cooperative Extension. (2011). 4-H TRY STEM: Teens reaching youth in science, technology, engineering and math [Site report]. Retrieved from http://urban4hscience.rutgers.edu/pdfs/TRY-STEM-Report.pdf

Worker, S.M. (2012). 4-H Science Abilities: Providing youth with opportunities to engage in the process of science [Fact sheet]. Retrieved from http://www.ca4h.org/files/131248.pdf

(c) Copyright of Journal of Youth Development Bridging Research and Practice. Content may not be copied or emailed to multiple sites or posted to a listserv without copyright holder's express written permission. Contact Editor at: patricia.dawson@oregonstate.edu for details. However, users may print, download or email articles for individual use.

ISSN 2325-4009 (Print); ISSN 2325-4017 (Online) 